\title{
Post-Soviet Politicized Media and Free Press within the Context of Central Asian Countries
}

\author{
Gönül Cengiz
}

\begin{abstract}
Central Asian countries (Kazakhstan, Turkmenistan, Uzbekistan, Kyrgyzstan and Tajikistan) were shaped their whole life by the Soviet rules since 1922 when came under the domination of USSR as colonial. Mass media of the Soviet Union countries carried out one communist party regime based politics was also used in accordance with the purpose and the wishes of this party. Trying to control or giving direction to this area by political actors in almost all communist theories under the influence of mass communication systems was discussed. Historical background of the Central Asian Republics was pushed "the media to being politicized" (Hallin and Mancini 2004, 61). The media adopted the spreading of Soviet ideology and the transmitting this to the community as the main task was seen as all of the political life, not as part of it. The Central Asian countries gained their independence could not escape from political situation of the media in the Post-Soviet period as well. The vast majority of journalists and media organizations operating in the country are directly or indirectly connected to politicians. The leaders of the mass media in this country have "good relations" with the ruling politicians. Articles on order and with the purpose of elevating or defamation someone are in common in newspapers. At the same time, there are confidential censorship and selfcensorship by the pressure of political power in Central Asian countries where officially banned the censorship. The news to be published on television and the articles in newspapers are delivered to the community after they are reviewed and approved in advance in a hidden way. Opposition media is too weak in Central Asian countries and one-way power media continues its dominance in this sector. Free activity of the media held under government pressure and control is prevented continuously. Today and the future of the free press is under threat in these five Central Asian countries debarred from wide-ranging and pluralist media.
\end{abstract}

Index Terms-Central Asia, politicized media, post-soviet, free press.

\section{INTRODUCTION}

Central Asian Republics continuing their presence among major opportunities and threats have a politically fragile structure. This situation nourishes the political stance legitimized and implemented all kind of political repression in order to protect the power.

From independence to present, protecting the current power against change in Central Asian countries was a determining factor in shaping domestic and foreign policies of these countries. Whereas many of these countries making efforts to be integrated into the international system, they pay attention to develop protective policies towards that

Manuscript received December 29, 2015; revised March 13, 2016.

G. Cengiz is with the Faculty of Communication, Marmara University, Turkey (e-mail: gonul.cengiz@marmara.edu.tr). such processes didn't lead to a change of power [1] (Alkan, http://www.erusam.com/images/dosya/Haluk_Alkan_konf_ metin.pdf , 2011). In The Soviet Union period, countries centralized to Moscow have no independent operations.

\section{Media During The Soviet ERA}

During the Soviet era, the media has a self-seeker role: media, which is seen as a form of ideological education, used as a tool to shape society's views by the Communist Party. Indeed, the Soviet approach to media had biased character. Because the mass media was exploited to transfer modern beliefs to the public, and as a transformative power. In Soviet period, access to all media in the country was being controlled by the Communist Party. There are positive and negative controls applied through the system carefully prepared by the management on whole party/state owned media organizations. This control has included having a voice in the appointment of media staff, conducting the training of journalists and imposition of a complex system in pre- and post-publication censorship [2] (Becker, 2002, pp. 1-45). Journalists are operated as extensions of the party apparatus and they act no different than others working in the field of ideological education.

In the USSR, media is identified with the party and remained subject to the party. At the same time, there are strict positive and negative controls maintained over whole press and applied regularly. Even though ideology lost its vitality in the last period of The Soviets, strict ideological control bounding society to a common language was continuing and there by any potential that may occur against the regime was restricting the opposition [3] (Becker, 2014, p. 194).

\section{MEDIA IN THE İNDEPENDENCE PERIOD}

In the early 1990s when the Central Asian republics have gained their independences very recently, the journalists had freer sphere of activity and the number of independent media organs has increased dramatically. During the first years of independence, the media was in experienced and was acting on his own. The media also had no financial responsibility and journalistic styles were not shaped yet. Because of the government couldn't reinforce the ruling power yet, their supervision on mass media was also so weak [4] (International Media Support Report, 2008, p. 14) Following the publishers, editors and writers' testing their limits of freedom excursively, independent activities of the media was dangerous according to governments in Central 
Asia since the late $1990 \mathrm{~s}$, and the media organs began to shut down with very little legal excuses. In these very early periods, power elites have employed to political and commercial methods in order to consolidate their authority in their own country [5] (Allison, 2006, p. 93).

Therefore, the failure of regime change and preventing the regime change are the most appropriate phrases used to describe the political and media landscape in Central Asia. In order to make a struggle with other political voices, the ruling families have embraced the media holding companies in the country and the state-controlled media organs have had a virtual monopoly on other visual and the written media in all Central Asian countries. [5] (Allison, 2006, p. 94)

There are many reasons on the basis of instability experienced in Central Asia. These are as follow; local conflicts, ethnic classes, conflicts over land and water resources, regime change and regional uncertainties caused by Afghanistan after 2004. These instabilities have affected the media directly or indirectly. Every volatile situation in these countries makes closer the media to the politics.

There are some similarities between management systems in the Central Asian Republics. The leaders are stayed in power for a long time in the region's countries and they are left no avenue unexplored to ensure that. These are significant similarities. The instinct of remain in power is caused inevitably to repressive tendencies, and pressure has become an important part of political experience [6] (Macit, 2012, pp. 50-51).

As there is not a stable political situation in the Central Asian Turkish Republics, USA and Western European countries are using this opportunity to their advantage. They use the media as the most effective medium in order to have a voice in Central Asia and move them away the Russian influence. Media organs such as "Internews", "Radio Liberty" and etc. operating in these republics are made Western propaganda and also the importance of Westernoriented media system in terms of democracy is mentioned frequently.

There is a huge role of the Western media in the Tulip Revolution erupted in Kyrgyzstan. The media screaming loudly for democratic elections in their headlines has been skillfully used in order to orient people. The West media also have a hand in the uprising occurred in Uzbekistan's Andijan province. [7] (Kenny, Gross, 2008, p. 516)

Regimes in Central Asia Countries can be divided into two parts according to approaches to the media: 1. Soft Authoritarian Regimes; 2. Hard Authoritarian Regimes

In soft authoritarian regimes, the state repression is performed as planned in a targeted and rational way, unlike hard authoritarian regime. It has a range of reasons. The first of these is that, in the soft authoritarianism, head of states avoid this kind of severe media repression so that not have shame for the country in the international arena. Kazakhstan and the Kyrgyz Republic are also improved their media activities in soft authoritarian environments [8] (Schatz, Maltseva, 2012, p. 46).

However, Turkmenistan and Uzbekistan has a media environment in hard authoritarian regime. Especially Turkmenistan has stayed very silent to critical responses from the international arena and continues the pressures applied to the media.

\section{TRANSITION FROM SOCIALISM TO CAPITALISM}

Socialism system prevailing during the Soviet era in the Central Asian Republics was forced to replace with capitalism system in these countries after their independence. These countries operating in socialist systems for many years have encountered great difficulties during the transition period to capitalism. According to capitalism, private sector approach has engaged and materiality has come into prominence in every work. This change was also available in the media. Changing the media, which is supporting the political authority and lighting the ideas of the party and state as media organ of the Communist Party for years, has not been easy for new order after many years. The media have begun to establish private sector and media organizations are concentrated in the hands of commercial parties, contrary to government. However, although Central Asian Republics adopted the capitalist system in their law, they still continue to bear the traces of socialism in their actual practices. For example, private broadcasting organizations in Uzbekistan, Kazakhstan and Kyrgyzstan cannot be made broadcasting in a way independent of the state. Though in a hidden way, they avoid publishing opposing ideas to the government and state. Television broadcasters give broadly place to news describing the activities of the ruling party in their programs and opinions of the opposition about the country have not been reflected in channels generally. Differently from these three countries, although Turkmenistan has been adopted doing business in the capitalist system, it is very difficult to see examples of capitalism in reality. The activities of the private broadcasting organizations have officially banned by Turkmenistan. It is irrelevant to talk about capitalism in a country where there is no private media. At the same time, members of the media did not even have the right to criticize the president in Turkmenistan. The media acting in accordance with the instructions of the president still cannot be disengaged from socialism. The media paying attention what they wrote and talk on behalf of the stability of the power could not escape being a state broadcasting organ as in the socialist system.

\section{POLITICIZED MEDIA AND GOVERNMENT İNTERVENTION IN FREE PRESS}

Political elites are followed up the media policies more actively day by day in order to put pressure on media and they take the necessary measures to ensure positive coverage. Richter (2008) [9] has identified the methods used for this purpose in Central Asian Republics:

1) State officials are oriented unofficial circulation in the media.

2) The state or state-controlled media infrastructure is refused to serve for independent or opposition media. For example, in Uzbekistan and Kazakhstan, printing and publishing companies managed by people close to the government shut its doors to the politicians with 
dissenting opinion and they serves the purposes of power.

3) Information and advertising restrictions are made for "treacherous and disloyal" media.

4) State's own subsidies and monopolies are exploited in favor of "faithful" media.

5) Ruling authorities are abused the regulatory and supervisory functions. For example, the authorities punish the "disloyal" media and reward the "faithful" media by using the licensing policies of broadcasting regulatory authority.

6) In-house censorship

7) Implementation of the illegal pressures to the responses giving by the media to the events in the country. The government and public officials raises extraordinary challenges to the media and journalists. These challenges include contents such as "censorship through physical assault and threatening" and "censorship by killing".

In Central Asian countries, we can see a lot of field of activity in which the media is politicized. For example, the first obstacle must be overcome by the owners of media organizations in the region countries is the registration process, and for this, that media either simply should not have a political opinion or it should have pro-government political views. Registration and licensing works must be gone through strict state control mechanisms.

Registration of media organizations varies by country and it takes between one month and 15 days with decisions of the related ministries (Information or the Ministry of Justice). However, the ministries making these registration works are working very slow most likely or they are deliberately prolonging the procedures by behaving "bad" to the opposition media. Registration bodies can be completed the registration procedures in a much more time than the expected time without any explanation and giving account. Although media experts think that some delays are due to the current wage failures, registration procedures are often arrested political reasons [5] (Allison, 2006, p. 97).

In Central Asian Republics, corruption rate is quite high. According to corruption perception index of Transparency International, all of the Central Asian Republics are in very poor condition in the world ranking. Corruption is also seriously affected the media.

The politicization of the media shows itself clearly in behaviors and attitudes of journalists. Journalists in the region didn't think that they are political guard or someone who is challenging political status quo. On the contrary, they see themselves as political players and they never require changing this role. They are working for a certain political "boss". In fact, "news" published for viewers, readers and listeners are propaganda of journalists transmitted from the perspective of political boss [10] (Oates, 2007, p. 1288).

The journalists who are making ordered news with bribery received from government become into the tools of politicians.

Considering the media ownership in the region countries, we can talk about an ownership structure due to political factors. Media ownership either directly depends on the state (such as Turkmenistan) or it is concentrated in the hands of businessmen and politicians close to the government.

Economy, which is part of the nature of governmentmedia relations, is more comprehensive and more detailed criteria than political and social control, in the determination of the media systems. As mentioned by Altschull, media has controlled by economic ways in former communist and post-communist societies. In former communist and socialist countries, media was constrained politically because it was economically dependent on government. At the same time, although the government made resource allocation for the media, it is able to distrain the profit and make the distribution of profit [11] (Ognianova, 1997, p. 5).

Central Asian Republics coming from the former socialist system was unable to leave traditions from the past in media industry and media ownership after declaring their independence. As in the Soviet period, the media ownership has enhanced in a state dependent way and it changes direction according to policies set by the government in the post-Soviet era.

In Central Asian countries, although it is known that most of the media holdings are in the hands of state officials and their relatives, their names are not in official documents. For example, Kazakhstan President Nursultan Nazarbayev's daughter Dariga Nazarbayeva manages the majority of the media sector in the country, but it is a very difficult to prove that because her name officially is not mentioned in many media companies [5] (Allison, 2006, p. 102).

In Central Asian countries, one of the most important factors of that the media has politicized is the financial commitment of media companies to the government. Commercial media companies have difficulties to make their activities long-term due to lower advertising revenues. These companies faced to shut down are forced to take refuge in government support. The media getting financial support from the state is inherently forced to pursue a policy pro-government.

Articles, news content prepared by members of the media in Central Asia contain many slander and insults that do not meet with Western standards. Thus, on one hand, journalists are accusing government officials; on the other hand, they become a guilty by breaching with the ethics of journalism. As such, it is set up an illegal connection between the government and the media and the media is deprived of democratic environment with its "own hands" a bit.

In Central Asian Republics, the absence of free, independent media system has taken roots as the most visible and the destructive evidence of the failure of civil society in these countries. Here, media are subject to restrictions imposed by government or non-government officials at all times including political elections and political opposition [12] (Freedman, Shafer, 2009, p. 861)

Government officials in the Central Asian Republics has common behaviors such as connecting the media to the regime through control and pressure and also squelching in order to acquiesce the regime by using the law with certain patterns. Some analysts suggested that different ways are followed in the political development of the Central Asian countries. But these changes do not affect the media seriously. For example, Uzbekistan's important leaning towards Russia and ongoing warm relations of Kyrgyzstan 
with the USA are not enough to recover the media from systematic oppression.

\section{CONCLUSION}

Neither the government nor journalists are fervently working to change this system. Even in the postrevolutionary environment in Kyrgyzstan; the space for independent media is shrinking with each passing day. Despite political changes, as long as regimes in Central Asian Republics kept all businesses in the country and all financial possibilities of the media under oppressive control, and as long as behaviors of journalists unfit for professional ethics continues and they followed the path to make work with bribe, media freedom will remain a distant goal in these republics.

\section{REFERENCES}

[1] H. Alkan. (2011). Political Systems in the Turkish Republics: 20 Annual balance sheet. [Online]. Available: http://www.erusam.com/images/dosya/Haluk_Alkan_konf_metin.pdf

[2] J. Becker, Soviet and Russian Press Coverage of the United States. Press, Politics, and Identity in Transition, Palgrave Macmillan, 2002, pp. 1-45.

[3] J. Becker, "Russia and the new authoritarians," Demokratizatsiya, no. 2, Spring, 2014, pp. 191-206.

[4] İnternational Media Support Report. (2008). The examples of Kazakhstan and Kyrgyzstan: Political extremism, terrorism, and media in central Asia. [Online]. Available: http://www.mediasupport.org/wp-content/uploads/2012/11/imspolitical-extremism-kyrgyzstan-kazahkstan-2008.pdf
[5] O. Allison, "Selective enforcement and irresponsibility: Central Asia's shrinking space for independent media," Central Asian Survey, vol. 25, no. 1-2, pp. 93-114, March-June, 2006.

[6] N. Macit. (Summer 2012). Where are the central Asian republics in terms of the plan for democracy Zoner / he Plan for Democracy Zoner I the Arabian Spring. [Online]. Available: http://www.tdid.ege.edu.tr/files/dergi_12/04.pdf

[7] T. Kenny and P. Gross, "Journalism in central Asia: A victim of politics, economics, and widespread self-censorship," The International Journal of Press/Politics, vol. 13, pp. 515-525, October 2008.

[8] E. Schatz and E. Maltseva, "Kazakhstan's authoritarian 'persuasion'," Post-Soviet Affairs, vol. 28, issue 1, pp. 45-65, 2012.

[9] A. Richter, "Post-soviet perspective on censorship and freedom of the media," The International Communication Gazette, vol. 70, no. 5, pp. 307-324, 2008.

[10] S. Oates, "The neo-soviet model of the media," Europe-Asia Studies, vol. 59, no. 8, pp. 1279-1297, December 2007.

[11] E. Ognianova, The transitional media system of post-communist Bulgaria, Association for Education in Journalism and Mass Communication, 1997, p. 5.

[12] E. Freedman and R. Shafer, "Press constraints as obstacles to establishing civil societies in central Asia developing a new model of analysis," Journalism Studies, vol. 10, no 6, pp. 851-869, 2009.

Gönül Cengiz is with Marmara University Research Assistant, Department of Radio-Television and Cinema. And she was born in Azerbaijan's capital Baku in 1988. Primary, secondary and high school education She has completed in Baku. She finished her undergraduate education in the Journalism Department of Baku State University. In 2010, She started to get a master's degree at radio, television and Cinema Department of Marmara University. In 2012, She completed her master and began to her $\mathrm{PhD}$ in the same department. Currently there continue my doctoral studies. She working on a thesis topic: "Comparative media systems in central Asian Turkish Republics" . 